\title{
Scheduled Maintenance
}

National Cancer Institute

\section{Source}

National Cancer Institute. Scheduled Maintenance. NCI Thesaurus. Code C111309.

An inspection and/or surveillance activity that has been anticipated to occur and was assigned a time or date when that activity is to be performed. 